\title{
Nutritional behaviours of pregnant women in rural and urban environments
}

\author{
Edyta Suliga' \\ 1 Institute of Nursing and Midwifery, Faculty of Health Sciences, Jan Kochanowski University, Kielce, Poland
}

Suliga E. Nutritional behaviours of pregnant women in rural and urban environments. Ann Agric Environ Med. 2015; 22(3): 513-517. doi: $10.5604 / 12321966.1167725$

\begin{abstract}
Introduction. Monitoring of the environmental differences in the mode of nutrition is especially important in pregnant women, for whom normal body weight gain is especially important for both the course of pregnancy and the normal development of the foetus, and is inseparably associated with rational nutrition.

Objective. The objective of the study was evaluation of the mode of nutrition of pregnant women according to the place of residence.

Materials and methods. The investigation comprised 704 women. Information was collected by means of an anonymous survey concerning place of residence, consumption of selected products and beverages, and taking folic acid and other vitamin and/or mineral dietary supplements.

Results. In the urban environment, pregnant women more frequently consumed vegetables, milk and dairy products, sea fish and wholemeal cereal products, drank more liquids, as well as more fruit and/or vegetable juices, and more often used the supplementation with folic acid, even before becoming pregnant. No significant differences were found in the consumption of fruits, pulses, products which are the source of complete proteins, confectionery products and sweets, according to the place of residence.

Conclusions. The diet of pregnant women from the rural environment compared to that of women from urban areas, was characterized by worse quality. It is necessary to carry out health education in the area of adequate nutrition among pregnant women, and those who plan pregnancy, directed primarily to all women from the rural environment.
\end{abstract}

\section{Key words}

pregnant women, nutritional behaviours, place of residence

\section{INTRODUCTION}

Socio-economic status is among the factors which considerably determine human health-related behaviours, the indicators of which are most frequently the amount of income and level of education $[1,2,3,4,5]$. In many countries, an important factor which also decides the mode of nutrition is place of residence $[6,7,8]$. The differences in nutritional behaviours between urban and rural inhabitants are also observed in Poland $[9,10,11,12]$. Monitoring of the environmental differences in the mode of nutrition is especially important in pregnant women, for whom normal body weight gain is of great importance for both the course of pregnancy and the normal development of the foetus, and is inseparably associated with rational nutrition.

Objective. The objective of the study was evaluation of the mode of nutrition of pregnant women according to the place of residence. Analysis also covered the nutritional status before pregnancy and average amounts of body weight gain during pregnancy.

\section{MATERIALS AND METHOD}

The study was conducted in 2012 in gynaecological-obstetric consultation rooms and outpatient departments in the Kielce

Address for correspondence: Edyta Suliga, Institute of Nursing and Midwifery, Faculty of Health Sciences, Jan Kochanowski University, Al. IX Wieków Kielc 19, 25-317 Kielce, Poland

E-mail: edyta.suliga@ujk.edu.pl

Received: 21 June 2013; accepted: 30 October 2013
Region of Poland, and covered 704 pregnant women. Data concerning 677 women were qualified for further analysis; $12.4 \%$ of them were in the first trimester of pregnancy, $25.4 \%$ in the second, and $62.2 \%$ in the third trimester of pregnancy. Information was collected by means of an anonymous survey concerning education, place of residence, age, consumption of selected products and beverages, and taking folic acid and other vitamin and/or mineral dietary supplements. The items in the questionnaire pertained to the number of portions of individual products consumed. The size of portions was specified according to the principles presented in literature [13]. From among the women in the study, 51\% came from the rural environment and 49\% were urban inhabitants; $21.0 \%$ possessed elementary education (elementary or elementary vocational), 37.7\% secondary school, and $41.3 \%$ higher education (licentiate or university Master's Degree). The highest percentage of women in the study were aged 25-34 $(62.6 \%), 26.3 \%$ of respondents were aged under 25 , including $2.4 \%$ of those under 18 . The reminder $(11.1 \%)$ were pregnant women aged 35 and over, including 1.3\% of those aged 40 and over. No significant differences in the distribution of age groups were observed between women living in rural and urban areas.

The respondents' nutritional status prior to pregnancy was evaluated using the declared data concerning body weight and height, based on which the BMI values were calculated. The present body weight of women in the $2^{\text {nd }}$ and $3^{\text {rd }}$ trimester of pregnancy served for the calculation of average amounts of weekly body weight gain. For pregnancies shorter than 38 weeks, the average weekly body weight gain was calculated by dividing body weight gain in pregnancy by the duration of pregnancy in weeks, whereas for pregnancies 


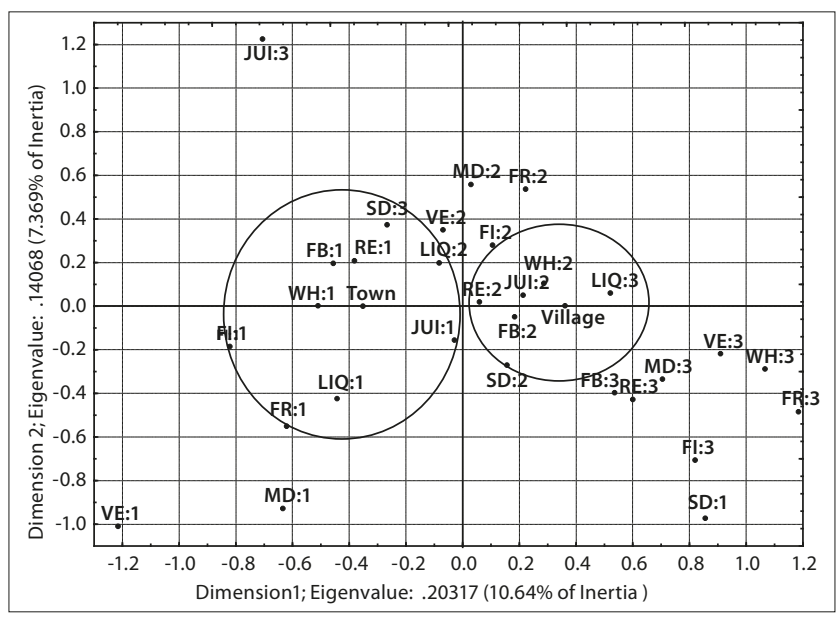

Figure 1. Relationship between mode of nutrition of pregnant women and place of residence - results of correspondence analysis

Place of residence - Town, Village; RE (regularity): 1 - yes, 2 - sometimes, 3 - no; FR (fruit): $1-\geq 3$ servings daily, $2-1-2$ servings daily, $3-<1$ serving daily; VE (vegetables): $1-\geq 3$ servings daily, $2-1-2$ servings daily, $3-<1$ serving daily; MD (milk and dairy products): $1-\geq 3$ servings daily, $2-1-2$ servings daily, $3-<1$ serving daily; $\mathrm{Fl}$ (sea fish): 1 - $\geq 1$ serving daily, $2-<1$ serving daily, 3 - not at all; WH (wholemeal products): $1-\geq 1$ serving daily, $2-<1$ serving daily, 3 - not at all; LIQ (liquids): $\geq 2$ litres, 2 - ca. 1.5 litres, $3-<1.5$ litres; JUI (juices): 1 -yes, 2 - sometimes, 3 - not at all; SD (sweet carbonated drinks): 1 - yes, 2 - sometimes, 3 - not at all; FB (beginning of taking folic acid): 1 - before pregnancy, 2 - at 1-12 weeks of pregnancy, 3 - after week 12 of pregnancy

longer than 38 weeks, by dividing body weight gain by 38 [14]. Subsequently, weekly amounts of body weight gain were categorized based on the distribution of this variable obtained in the representative studies of Polish women conducted by Borkowski and Mielniczuk [15]. Three categories of weight gain were distinguished: low (from $0.29 \mathrm{~kg} /$ week), mediocre (0.29-0.44 kg/week), and high (over $0.44 \mathrm{~kg} /$ week). Statistical analysis was performed using correspondence analysis (Fig. 1.), and non-parametric chi-square test $(\chi 2)$ test (Tab. 1, 2, 3, 4, 5). The $\mathrm{p}$ values $\mathrm{p}<0.05$ were considered statistically significant.

\section{RESULTS}

More than $47 \%$ of the women in the study consumed 5 or more meals daily, and over $74 \%$ snacked between meals at least once daily (Tab. 1). No differences were observed according to the place of residence, or in the number of meals consumed during the day, nor the frequency of snacking between meals; however, regular consumption of meals in

Table 1. Characteristics of nutritional habits of the women examined (\%)

\begin{tabular}{|c|c|c|c|c|}
\hline \multirow{2}{*}{ Nutritional habits } & \multirow{2}{*}{ category } & \multicolumn{3}{|c|}{ Place of residence } \\
\hline & & rural & urban & total \\
\hline \multirow{3}{*}{$\begin{array}{l}\text { No. of meals during the day } \\
p=0.6837\end{array}$} & $\leq 3$ & 16.9 & 18.4 & 17.6 \\
\hline & 4 & 33.4 & 36.6 & 35.0 \\
\hline & $\geq 5$ & 49.7 & 45.1 & 47.4 \\
\hline \multirow{3}{*}{$\begin{array}{l}\text { Regular consumption of } \\
\text { meals } \\
\mathbf{p}=\mathbf{0 . 0 0 0 8}\end{array}$} & yes & 31.0 & 44.7 & 37.7 \\
\hline & sometimes & 43.5 & 37.2 & 40.4 \\
\hline & no & 25.5 & 18.1 & 21.9 \\
\hline \multirow{4}{*}{$\begin{array}{l}\text { Snacking between meals } \\
p=0.5104\end{array}$} & no & 9.6 & 13.0 & 11.2 \\
\hline & more rarely than once daily & 14.2 & 15.1 & 14.6 \\
\hline & once daily & 29.6 & 28.4 & 29.0 \\
\hline & several times daily & 46.7 & 43.5 & 45.1 \\
\hline
\end{tabular}

Table 2. Consumption of selected food products according to place of residence (\%)

\begin{tabular}{|c|c|c|c|c|}
\hline \multirow{2}{*}{ Products } & \multirow{2}{*}{ Frequency of intake } & \multicolumn{3}{|c|}{ Place of residence } \\
\hline & & rural & urban & total \\
\hline \multirow{4}{*}{$\begin{array}{l}\text { Fruit } \\
p=0.5647\end{array}$} & $<1$ serving daily & 10.4 & 12.7 & 11.5 \\
\hline & 1 - 2 servings daily & 53.9 & 47.7 & 50.9 \\
\hline & 3 servings daily & 24.4 & 26.3 & 25.3 \\
\hline & 4 or more servings daily & 11.3 & 13.3 & 12.3 \\
\hline \multirow{4}{*}{$\begin{array}{l}\text { Vegetables } \\
\mathbf{p}=\mathbf{0 . 0 0 4 6}\end{array}$} & $<1$ serving daily & 29.0 & 19.2 & 24.1 \\
\hline & 1 - 2 servings daily & 60.8 & 58.1 & 59.6 \\
\hline & 3 servings daily & 7.0 & 15.0 & 10.9 \\
\hline & $\geq 4$ servings daily & 3.2 & 7.7 & 5.4 \\
\hline \multirow{3}{*}{$\begin{array}{l}\text { Pulses } \\
p=0.3268\end{array}$} & not at all & 32.8 & 29.9 & 31.4 \\
\hline & $<1$ serving in a week & 51.3 & 49.9 & 50.6 \\
\hline & $\geq 1$ serving in a week & 15.9 & 20.2 & 18.1 \\
\hline \multirow{4}{*}{$\begin{array}{l}\text { Meat, fish, eggs total } \\
p=0.4834\end{array}$} & $<1$ serving daily & 20.3 & 15.7 & 18.1 \\
\hline & 1 - 2 servings daily & 58.8 & 61.9 & 59.9 \\
\hline & 3 servings daily & 16.2 & 16.9 & 16.6 \\
\hline & $\geq 4$ serving daily & 5.5 & 5.4 & 5.5 \\
\hline \multirow{4}{*}{$\begin{array}{l}\text { Milk and dairy products } \\
\mathbf{p}=\mathbf{0 . 0 3 3 8}\end{array}$} & $<1$ serving daily & 22.0 & 17.6 & 19.7 \\
\hline & 1 - 2 servings daily & 55.9 & 50.3 & 53.6 \\
\hline & 3 servings daily & 11.9 & 17.1 & 14.6 \\
\hline & $\geq 4$ servings daily & 9.2 & 15.0 & 12.1 \\
\hline \multirow{3}{*}{$\begin{array}{l}\text { Sea fish } \\
p=0.0005\end{array}$} & not at all & 22.0 & 12.4 & 17.3 \\
\hline & $<1$ serving in a week & 57.4 & 57.7 & 57.5 \\
\hline & $\geq 1$ servings in a week & 20.6 & 29.9 & 25.2 \\
\hline \multirow{4}{*}{$\begin{array}{l}\text { Wholemeal cereal products } \\
\mathbf{p}=\mathbf{0 . 0 0 4 8}\end{array}$} & not at all & 17.1 & 9.9 & 13.6 \\
\hline & $<1$ serving daily & 40.6 & 36.6 & 38.6 \\
\hline & 1 serving daily & 27.3 & 29.0 & 28.1 \\
\hline & $\geq 2$ servings daily & 15.1 & 24.5 & 19.7 \\
\hline \multirow{4}{*}{$\begin{array}{l}\text { Confectionery } \\
\text { and sweets } \\
p=0.2648\end{array}$} & not at all & 7.8 & 9.1 & 8.4 \\
\hline & several servings in a week & 54.5 & 55.9 & 55.2 \\
\hline & 1 serving daily & 24.1 & 19.3 & 21.8 \\
\hline & $\geq 2$ servings daily & 13.6 & 15.7 & 14.6 \\
\hline
\end{tabular}

pregnancy was significantly more often declared by urban inhabitants.

In the urban environment, pregnant women more frequently consumed vegetables, milk and dairy products, sea fish and wholemeal cereal products (Tab. 2). No significant differences were found in the consumption of fruits, pulses, products which are the source of complete proteins, confectionery products and sweets, according to the place of residence. Six from among the women examined $(0.89 \%)$ did not consume meat and cold cuts, including 2 living in rural $(0.58 \%)$ and 4 in urban environments (1.20\%).

No significant differences were observed in the consumption of alcoholic beverages, strong tea and coffee, as well as fizzy drinks containing caffeine, according to the place of residence (Tab. 3). Urban inhabitants generally drank more liquids, more fruit and/or vegetable juices, and also reported that in pregnancy they avoided the consumption of sweetened fizzy drinks, and more often used the supplementation with folic acid even before becoming pregnant (Tab. 4).

The results of correspondence analysis showed that the urban place of residence was most strongly related with the 
Table 3. Consumption of selected beverages according to place of residence $(\%)$

\begin{tabular}{|c|c|c|c|c|}
\hline \multirow{2}{*}{ Intake of beverages } & & \multicolumn{3}{|c|}{ Place of residence } \\
\hline & & rural & urban & total \\
\hline \multirow{3}{*}{$\begin{array}{l}\text { Liquids total } \\
\mathbf{p}=\mathbf{0 . 0 0 7 5}\end{array}$} & $<1.5$ litres & 33.6 & 23.9 & 28.9 \\
\hline & ca. 1.5 litres & 44.6 & 46.5 & 45.6 \\
\hline & $\geq 2$ litres & 21.7 & 29.6 & 25.6 \\
\hline \multirow{3}{*}{$\begin{array}{l}\text { Fruit and/or vegetable juices } \\
\mathbf{p}=\mathbf{0 . 0 2 8 4}\end{array}$} & yes & 58.0 & 67.2 & 62.7 \\
\hline & seldom & 33.5 & 27.9 & 30.7 \\
\hline & not at all & 8.5 & 4.9 & 6.7 \\
\hline \multirow{3}{*}{$\begin{array}{l}\text { Sweetened fizzy drinks in general } \\
\mathbf{p}=\mathbf{0 . 0 3 7 2}\end{array}$} & yes & 10.9 & 10.3 & 10.6 \\
\hline & seldom & 42.8 & 33.8 & 38.4 \\
\hline & not at all & 46.3 & 55.9 & 51.0 \\
\hline \multirow{3}{*}{$\begin{array}{l}\text { Fizzy drinks containing caffeine } \\
p=0.8716\end{array}$} & yes & 7.0 & 6.9 & 7.0 \\
\hline & seldom & 39.4 & 37.5 & 38.4 \\
\hline & not at all & 53.6 & 55.6 & 54.6 \\
\hline \multirow{3}{*}{$\begin{array}{l}\text { Coffee } \\
p=0.6944\end{array}$} & yes & 12.5 & 13.0 & 12.8 \\
\hline & seldom & 30.0 & 32.7 & 31.4 \\
\hline & not at all & 57.4 & 54.2 & 55.9 \\
\hline \multirow{3}{*}{$\begin{array}{l}\text { Strong tea } \\
p=0.2601\end{array}$} & yes & 20.9 & 17.0 & 19.0 \\
\hline & seldom & 42.4 & 40.7 & 41.6 \\
\hline & not at all & 36.8 & 42.3 & 39.5 \\
\hline \multirow{2}{*}{ Alcoholic beverages $p=0.3231$} & yes & 15.0 & 17.8 & 16.4 \\
\hline & not at all & 85.0 & 80.2 & 83.6 \\
\hline
\end{tabular}

Table 4. Taking folic acid and other dietary supplements (\%)

\begin{tabular}{|c|c|c|c|c|}
\hline \multirow{2}{*}{ Taking of supplements } & & \multicolumn{3}{|c|}{ Place of residence } \\
\hline & & rural & urban & total \\
\hline \multirow{2}{*}{$\begin{array}{l}\text { Folic acid } \\
p=0.0770\end{array}$} & yes & 85.2 & 89.7 & 87.4 \\
\hline & no & 14.8 & 10.3 & 12.6 \\
\hline \multirow{3}{*}{$\begin{array}{l}\text { Commencement of taking } \\
\text { folic acid } \\
\mathbf{p}=\mathbf{0 . 0 0 8 5}\end{array}$} & before pregnancy & 28.2 & 40.3 & 34.3 \\
\hline & at $1-12$ weeks of pregnancy & 60.5 & 50.7 & 55.6 \\
\hline & after week 12 of pregnancy & 11.2 & 9.1 & 10.1 \\
\hline \multirow{2}{*}{$\begin{array}{l}\text { Other supplements } \\
p=0.4903\end{array}$} & yes & 39.1 & 36.6 & 37.9 \\
\hline & no & 60.9 & 63.4 & 62.1 \\
\hline \multirow{2}{*}{$\begin{array}{l}\text { Polyunsaturated fatty } \\
\text { acids } n-3 \\
p=0.0680\end{array}$} & yes & 29.8 & 38.3 & 34.1 \\
\hline & no & 70.2 & 61.7 & 66.0 \\
\hline
\end{tabular}

Table 5. Nutritional status before pregnancy and average amounts of body weight gain in pregnancy (\%)

\begin{tabular}{|c|c|c|c|c|}
\hline \multirow{2}{*}{\multicolumn{2}{|c|}{ Nutritional status and amounts of body weight gain }} & \multicolumn{3}{|c|}{ Place of residence } \\
\hline & & rural & urban & total \\
\hline \multirow{3}{*}{$\begin{array}{l}\text { Nutritional status before } \\
\text { pregnancy }\left(\mathrm{BMI} \mathrm{kg} / \mathrm{m}^{2}\right) \\
p=0.2305\end{array}$} & underweight $(<18.5)$ & 6.4 & 8.2 & 7.3 \\
\hline & normal weight (18.5-24.9) & 71.5 & 74.5 & 73.0 \\
\hline & overweight ( $\geq 25.0$ ) & 22.1 & 17.3 & 19.7 \\
\hline \multirow{3}{*}{$\begin{array}{l}\text { Average amounts of body } \\
\text { weight gain ( } \mathrm{kg} / \text { week) } \\
p=0.9975\end{array}$} & low & 39.6 & 39.8 & 39.7 \\
\hline & mediocre & 32.8 & 32.8 & 32.8 \\
\hline & high & 27.5 & 27.4 & 27.5 \\
\hline
\end{tabular}

regular consumption of meals, taking folic acid even before becoming pregnant, high consumption of wholemeal cereal products, drinking a greater amount of liquids, including more frequent consumption of fruit and/or vegetable juices, and avoidance of sweetened fizzy drinks, and also with a high consumption of fruits and sea fish (Fig. 1). The rural place of residence was most strongly related with taking folic acid at 1-12 weeks of pregnancy, lower consumption of wholemeal cereal products, drinking small amounts of liquids in general, including more rare consumption of fruit and/or vegetable juices, a slightly more frequent consumption of sweetened fizzy drinks, and also less regular consumption of meals.

In addition, the respondents' nutritional status before pregnancy and the amounts of average body weight gain in pregnancy were analyzed according to the place of residence (Tab. 5). However, no significant differences were found between the urban and rural inhabitants. It was only noted that the percentage of pregnant women with an excessive body weight was slightly higher in the rural than urban environment; nevertheless, this difference was statistically insignificant.

\section{DISCUSSION}

The results of many studies confirm that the diet of pregnant women with low socio-economic standard is characterized by a poorer quality $[16,17,18,19,20,21]$. Low education level and lack of sufficient financial resources for the purchase of the necessary food products significantly limited the consumption by pregnant women of vitamin and/or mineral dietary supplements, and products such as: fruits, vegetables, milk and dairy products, sea fish, wholemeal cereal products, and products which are the source of animal proteins. In contrast, the consumption of sweetened fizzy drinks was higher in the group of women with a lower education level and declared financial deficits [19]. The analysis performed indicated that pregnant women in the rural environment in the Kielce Region more rarely consumed vegetables, milk and dairy products, sea fish, and wholemeal cereal products, drank less liquids in general and less fruit and/ or vegetable juices, compared to pregnant women from the urban environment, and also more rarely avoided the consumption of sweetened fizzy drinks. These results are in accordance with the results of all-Polish studies which showed that rural pregnant women considerably less frequently consumed meat, raw and boiled salads, fruits, milk, dairy products and eggs, more rarely drank water, whereas more often - tea [11]. Despite differences in the mode of nutrition between urban and rural women, no analogous differences in haematological parameters after delivery were noted. However, babies of mothers from the urban environment had a higher level of haemoglobin [22]. In addition, the results of own studies indicate that urban inhabitants consumed meals more regularly than rural women, and more often used the supplementation with folic acid even before becoming pregnant.

Thus, the results of the presented study confirmed that the diet of women from the rural environment was poorer from the aspect of quality, compared to the diet of pregnant women living in the urban areas. The differences in the mode of nutrition among the inhabitants of urban and rural areas in Poland, on the one hand, are due to a greater attachment to the traditional way of nutrition and smaller susceptibility to the beneficial nutritional changes [23], and on the other hand, greater impoverishment in rural areas and, in consequence, smaller possibilities to satisfy 
nutritional needs [10]. Rural inhabitants more frequently than urban inhabitants mentioned the necessity to resign, for financial reasons, from the purchase of such groups of foods as: fish and fish products (24\% of rural households), confectionery (18\%), stimulants $(17 \%)$, meat and poultry (16\%), as well as fruits and fruit products (14\%) [10].

In the Kielce Region, the percentage of rural women who consumed alcohol in pregnancy reached $15 \%$, and that of urban women $-17.8 \%$, which is similar to that obtained in the all-Polish study, in which drinking alcohol was admitted by $12 \%$ rural women, $20 \%$ of women living in cities with a population of over 100,000 , and more than $15 \%$ of inhabitants of small towns [24]. Also, Wojtyła et al. confirmed that 15\% of Polish women consumed alcohol during the entire period of pregnancy [25]. The review of literature performed by Skagerstróm et al. [26] confirmed that high income and/or high social status are conducive to drinking alcohol during pregnancy.

Age is among the factors which may modify the mode of nutrition of pregnant women. The results of the presented study, analysed generally, showed that women aged 35 and over, compared to younger women, in pregnancy, more often consumed sea fish, wholemeal products, and sweets, and were more often overweight (32\% of respondents), while they less frequently consumed coffee (data not shown). Women aged 25-34, most often started to take folic acid before becoming pregnant. No significant differences were observed in the frequency of consumption of the remaining products and beverages. Nevertheless, the distribution of age groups of rural and urban women did not significantly differ; therefore, this factor had no effect on the differences in the mode of nutrition of pregnant women from both environments compared.

Despite the differences in the frequency of consumption of many products and beverages, no differences were observed among the women in the study in the average amounts of body weight gain in pregnancy according to the place of residence. This partially results from the fact that the amounts of body weight gain depend on body weight before pregnancy [14], and the pregnant women in both environments did not significantly differ from the aspect of the frequency of occurrence of both deficit and excess of body weight. In addition, the amounts of body weight gain depended primarily on the energy value of the diet, and not its quality. Nevertheless, the effect of a diet which is worse from the aspect of quality are usually deficient in many nutrients (vitamins, mineral components, unsaturated fatty acids), and an excess of, among others, monosaccharides, unsaturated fat with trans-isomer fatty acids and fat in general [5], which exerts a negative effect on the course of pregnancy, development of the foetus and health of the woman. A lower level of knowledge concerning food and nutrition, and consumption of diet worse from the aspect of quality may also result in the lower health safety of food, and may be the cause of bacterial or parasitic infections. Both the occurrence of infection and the treatment applied may also have a negative effect on the course of pregnancy and development of the foetus [27]. Therefore, the promotion of an adequate diet should become an integral part of the medical services provided for pregnant women, and women who plan pregnancy, and constitute one of the priority goals of the health policy of the State.

\section{CONCLUSIONS}

The diet of pregnant women from the rural environment, compared to that of women from urban areas, was characterized by worse quality, resulting primarily from the lower consumption of milk and dairy products, sea fish, wholemeal cereal products, vegetables, and fruit and/or vegetable juices. It was also noted that rural women more rarely took folic acid, even before becoming pregnant, and consumed meals less regularly.

No significant differences in nutritional status were observed before pregnancy and the amounts of average body weight gain during pregnancy, according to the place of residence.

It is necessary to carry out health education in the area of adequate nutrition among pregnant women, and those who plan pregnancy, directed primarily to all women from the rural environment.

\section{REFERENCES}

1. Desmukh-Taskar P, Nicklas TA, Yang SJ, Berenson GS. Does food group consumption vary by differences in socioeconomic, demographic, and lifestyle factors in young adults? The Bogalusa Heart Study. J Am Diet Assoc. 2007; 107: 223-234.

2. Mullie P, Clarys P, Hulens M, Vanasant G. Dietary patterns and socioeconomic position. Eur J Clin Nutr. 2010; 64: 231-238.

3. Boylan S, Lallukka T, Lahelma E, Pikhart H, Malyutina S, Pajak A, et al. Socio-economic circumstances and food habits in Eastern, Central and Western European populations. Public Health Nutr. 2011; 14: 678-687.

4. Kriaucioniene V, Klumbiene J, Petkeviciene J, Sakyte E. Time trends in social differences in nutrition habits of a Lithuanian population: 1994 2010. BMC Public Health 2012; 21: 218. doi: 10.1186/1471-2458-12-218.

5. Monsivas P, Aggarwal A, Drewnowski A. Are socio-economic disparities in diet quality explained by diet cost? J Epidemiol Community Health. 2012; 66: 530-535.

6. Lutfivva MN, Chang LF, Lipsky MS. A cross-sectional study of US rural adults' consumption of fruits and vegetables: do they consume at least five servings daily? BMC Public Health 2012; 12: 280. doi: 10.1186/1471-2458-12-280.

7. Tsigga M, Filis V, Hatzopoulou K, Kotzamanidis C, Grammatikopoulou MG. Healthy Eating Index during pregnancy according to pre-gravid and gravid weight status. Publ Health Nutr. 2011; 14: 290-296. doi: 10.1017/S1368980010001989.

8. Cesani MF, Garraza M, Bergel Sanchis ML, Luis MA, Torres MF, Quintero FA, et al. A comparative study on nutritional status and body composition of urban and rural schoolchildren from Brandsen district (Argentina). PLoS One. 2013; 8: e52792. doi: 10.1371/journal. pone.0052792.

9. Krzyczycha R, Szponar B. Body mass index (BMI) and dietary preferences of women living in rural areas. Ann Nat Inst Hyg. 2009; 60: 75-77.

10. Social Diagnosis 2011. Objective and Subjective Quality of Life in Poland. Czapiński J, Panek T (Eds). The Council for Social Monitoring, Warsaw 2012

11. Wojtyła A, Bojar I, Boyle P, Zatoński W, Marcinkowski JT, Biliński P. Nutritional behaviours among pregnant women from rural and urban environments in Poland. Ann Agric Environ Med. 2011; 18: 169-174.

12. Suliburska J, Bogdański P, Duda G, Pupek-Musialik D, Piątek J, Żukiewicz-Sobczak W. An assessment of dietary intake and state of nutritional in hypertensive patients from rural and urban areas of Greater Poland. Ann Agric Environ Med. 2012; 19: 339-343.

13. Szostak-Węgierek D, Cichocka A. Żywienie kobiet w ciąży. PZWL, Warsaw, 2005 (in Polish).

14. Shieve LA, Cogswell ME, Scanlon KS, Perry G, Ferre C, BlackmorePrince C. Prepregnancy body mass index and pregnancy weight gain: association with preterm delivery. Obstet Gynecol. 2000; 96: 194 -200.

15. Borkowski W, Mielniczuk H. Preterm delivery in relation to combined pregnancy weight gain and prepregnancy body mass. Przegl Epidemiol. 2007; 61: 577-584. 
16. Sontrop JM, Campell MK, Evers SE, Speechley KN, Avison WR. Fish consumption among pregnant women in London, Ontario: associations with socio-demographic and health and lifestyle factors. Can J Pub Health. 2007; 98: 389-394

17. Northstone K, Emmett P, Rogers I. Dietary patterns in pregnancy and associations with sociodemographic and lifestyle factors. Eur J Clin Nutr. 2008; 62: 471-479.

18. Suliga E. Nutritional behaviours of pregnant women. Pediatr Endocrinol Diabet Metab 2011; 17: 76-81.

19. Suliga E. Economic and social factors and the quality of nutrition of pregnant women. Med St. 2013; 29: 160-166.

20. Fowles ER, Bryant M, Kim SH. Predictors of dietary quality in lowincome pregnant women: a path analysis. Nurs Res. 2011; 60: 286-294.

21. Ebrahimi F, Shariff ZM, Rezaeian M, Tabatabaei SZ, Mun CY, Tajik E. Socioeconomic status and intake of energy and sodium are associated with calcium intake among pregnant women in Rafsanjan city. Iran. J Obstet Gynaecol Res. 2013; 39: 146-153.
22. Wojtyła C, Biliński P, Paprzycki P, Warzocha K. Haematological parameters in postpartum women and their babies in Poland comparison of urban and rural areas. Ann Agric Environ Med. 2011; 18: 380-385.

23. Kirschner H, Kosińska I, Narojek L. Changes in nutritional behavior in Poland in the nineties. Pol J Publ Health. 2002; 112: 313-319.

24. Raport $\mathrm{z}$ analizy danych ankietowych pochodzacych $\mathrm{z}$ badania: Zachowania zdrowotne kobiet w ciąży. Warszawa, Główny Inspektorat Sanitarny, 2009 (in Polish).

25. Wojtyła A, Kapka-Skrzypczak L, Diatczyk J, Fronczak A, Paprzycki P. Alcohol-related Developmental Origin of Adult Health - population studies in Poland among mothers and newborns (2010-2012). Ann Agric Environ Med. 2012; 19: 365-377.

26. Skagerstróm J, Chang G, Nilsen P. Predictors of drinking during pregnancy: a systematic review. J Women's Health 2011; 20: 901-913.

27. Ehmke vel Emczyńska E, Bebelska K, Czerwonogrodzka-Senczyna A. The importance of dietary counseling in the prevention of complications of pregnancy. Med News. 2012; 81: 273-280. 